\title{
TEACHING WRITING USING PREPARE ORGANIZE WRITING EVALUATE RETHINK STRATEGY AT THE EIGHT GRADE OF MTS MAHWIL UMMIYAH MUARA LAPA DAYA DUNGKEK SUMENEP IN THE ACADEMIC YEAR OF 2019/2020
}

\author{
Ummul Khoiroh \\ Pendidikan Bahasa Inggris, Fakultas Ilmu Pendidikan, Universitas Hasym Asy'ari \\ Khoirahone96@gmail.com \\ Haris Supratno \\ Universitas Hasyim Asy'ari, Tebuireng, Jombang \\ harissupratno@unesa.ac.id \\ Ria Kamilah Agustina \\ Pendidikan Bahasa Inggris, Fakultas Ilmu Pendidikan, Universitas Hasym Asy'ari \\ riakamilah88@gmail.com
}

\begin{abstract}
Writing learning using P.O.W.E.R. strategy that occurs in the eight class of MTs Mahwil Ummiyah make innovative and inspiring learning, the students innovatively to creative study and independent, the strategy is involving students to evaluate and revise independently who crated students in writing. The goal is the POWER method to be achieved in the writing learning effectively, to descript the students of result in the writing learning using the POWER method. The technique data analysis data reduction the researcher observe in the field, data display to descript the result, conclusion is the verification. The result of this research can be seen in the 4 cycles of learning process. $20,5 \%$ is the students learning result from first cycle in the second cycles out $72 \%$ in the third cycles $85 \%$ in the fourth $91 \%$. Can conclude that students writing learning was drastic increase. this shows that the learning process using the POWER method of students in MTs Mahwil Ummiyah successfully.
\end{abstract}

Keyword: Teaching Writing Using P.O.W.E.R Method

\section{INTRODUCTION}

Education is an agent of change that provides good potential for students, education can increase the potential of students to create creative and inspiring individuals. According to Nurkholis (2013: 32) an activity that has the aim of developing and educating one's soul, in this era of course education is very necessary as a guide to live a life that is increasingly developing, education can spur the character of students and change the behavior of students.

The development of science and technology in this modern era makes it easier for students to learn more instantly, meaning that they don't waste a lot of time and space, learn more easily and quickly, but also among those students who misuse science and technology on negative sites. that's why don't let students freely use technological tools. Learning is said to be successful if students want to learn again from mistakes made previously, meaning that they don't give up easily with just one chance, they feel addicted to learning again and again.

The teacher is the first person who has an important role in education, as a supporter of developing education among students, according to Agustinus (2018: 165) a teacher is someone who is needed at any time, where teachers must have many ways to educate and nurture students besides that teachers must educate the nation's children as the next generation. However, the task of a teacher is not only to convey material and educate the nation's children, but more importantly, teachers 
must be able to be good role models to students.

Every student has the right to get good learning from a teacher, the right teacher is a teacher who understands the environmental conditions of students, so from there the teacher does not always deliver teaching using the same method every day, teaching methods for students will create conditions active when learning takes place, students tend to be bored with one learning method, researchers try to turn on the activities of students in class by providing new methods for them, which this method has not been used by previous teachers.

POWER is the first method applied among MTs Mahwil Ummiyah, POWER is a method that has 4 steps Prepare, Organize, Writing, Evaluate and Revising. This method is cooperative learning in which students will be formed into groups of 2 or 3 students. This learning technique requires students to work together to exchange information, exchange ideas and discuss together in groups. students will go through the first 4 steps, namely Prepare, where researchers prepare teaching materials before teaching begins, Organize, namely students will be grouped into several groups, Writing, namely students who deliberately form several groups to discuss the tasks given by the researcher, Evaluate, namely is an activity resulting from the broadening of the discussion that has been carried out by each student in each group, Revising is the result of group work analysis, where in this case the students make joint improvements to an incorrect sentence.

Based on the research objectives, using this method is to develop the writing potential of each student, provide motivation and broad insights as a reference for students' writing talents. Previously, researchers noticed the condition of students who were less active in learning to write, many of them lacked confidence in their own abilities.

Based on observations made by researchers on April 12, 2020 by choosing the title Teaching Writing Using Prepare Organize Writing Evaluate Rethink
Strategy at the Eight Grade of MTs Mahwil Ummiyah Muara Lapa Daya Dungkek Sumenep in the academic year of 2019/2020.

In this study, there were several problem formulations, namely, What is the teaching and learning process teachers by using the P.O.W.E.R method in teaching writing? Research the problems was face by the teacher using the P.O.W.E.R method? What is result of teachinglearning by using the P.O.W.E.R method? What is the effect of the P.O.W.E.R method of teaching writing to students?

Researchers followed learning directly in the field, with students in order to find out students' responses to learning methods delivered by researchers. Each student feels prioritized by the researcher because so far the method they have obtained has not changed, the researcher sees students are very responsive to learning using the POWER method during the teaching and learning process students are quite active in discussing and working together in groups, problems encountered during the process teaching and learning according to Nisa '(2017: 01) the problem that often occurs in educating is that students are not competent in learning to write in the sense that students' low writing ability. Based on the cycles that were carried out for 4 cycles, the results obtained during the teaching and learning process were quite good and succeeded in achieving the KKM score criteria determined by the researcher.

Based on the findings obtained in the field on the impact of learning the POWER method, the POWER method helps students improve their writing skills with the right grammar structure effectively. The POWER method develops students' motivation to learn creative writing. The material used by the researcher was Recount text. This research was conducted in the eighth grade of MTs Mahwil Ummiyah with 40 students as respondents. This study aims to determine the development of motivation and talents of students in learning to write. Researchers deliberately used new methods of learning to support students' learning to write to be more creative and active. 


\section{METHOD}

This type of research uses qualitative and quantitative research types, which are conducted in eight classes of MTs Mahwil Ummiyah. During the teaching and learning process in the classroom researchers use two types of research at once because researchers need descriptive explanations and numerical explanations. The descriptive explanation of the researcher used interviews and questionnaires as data while explanation of the researcher used from 4 cycles. According to Mulyadi (2011: 131) qualitative research is research carried out in real conditions, qualitative research describes events that occur in the field in detail and the process of finding numerical data that is quantitative research.

This research uses interview, observation, questionnaire, and test methods. Interviews were conducted at the time of learning planning with the aim of researchers wanting to know the conditions of the learning environment needed by students in the field, observations were carried out with the aim of knowing the value of student and teacher activities carried out by observers, questionnaires were given to students with the aim of researchers wanting to know student learning improvement in 4 cycles, the test is carried out during the learning hours in the field with the aim of knowing the students' mastery of understanding the writing learning method using POWER.

The observation sheet is the observer's note that is used as an assessment of the researcher in the teaching and learning process. Interview sheets are used as a medium for questions or statements consisting of concepts, facts, opinions and perceptions. Test sheets are used to be distributed to students as a means of assessing mastery of learning material. The questionnaire sheet as a respondent's review of the research.

In this research the validity used Perseverance which in the teaching and learning process in the classroom followed by researcher. Trianggulation, which is data checking activity, through observation, interview and documentation, the data is obtained from three techniques through comparison and analysis are pre-test and post-test.

The following is a post-test and pretest table used by researchers as a review of mastery of recount text material using the POWER method.

Table 1. Content Validity of Pre-test

\begin{tabular}{|l|l|l|l|l|}
\hline No & Indicators & \multicolumn{3}{|c|}{ Score } \\
\cline { 3 - 5 } & & Excellent & Good & Enough \\
\hline 1. & To explain the title using own language & A & B & C \\
\hline 2. & To explain the point on the title & A & B & C \\
\hline 3. & To explain the phenomenon on their childhood & A & B & C \\
\hline 4. & To explain the memorians on their childhood & A & B & C \\
\hline 5. & To explain the situation on their childhood & A & B & C \\
\hline
\end{tabular}

Table 2. Content Validity of Post-test

\begin{tabular}{|l|l|l|l|l|}
\hline No & Indicators & \multicolumn{3}{|c|}{ Score } \\
\cline { 3 - 5 } & & Excellent & Good & Enough \\
\hline 1. & To explain the title using own language & A & B & C \\
\hline 2. & To explain the point on the title & A & B & C \\
\hline 3. & To explain the phenomenon on their childhood & A & B & C \\
\hline 4. & To explain the memorians on their childhood & A & B & C \\
\hline 5. & To explain the situation on their childhood & A & B & C \\
\hline
\end{tabular}

\section{FINDING AND DISCUSSION}

The researcher will explain the results of research conducted in the field during the eighth grade teaching and learning process at MTs Mahwil Ummiyah. Below is a table of materials that were applied to eighth grade students of MTs Mahwil Ummiyah as 
research materials using the POWER method.

Table 3. Materials that were applied to eighth grade students

\begin{tabular}{|c|l|}
\hline 1. & Different verb 1, verb 2, and verb 3 \\
\hline 2. & $\begin{array}{l}\text { Make a sentence to tell about their } \\
\text { childhood, recount text }\end{array}$ \\
\hline 3. & $\begin{array}{l}\text { Make a dialog sentence about a } \\
\text { phenomenon in their school was passed }\end{array}$ \\
\hline 4. & $\begin{array}{l}\text { Tell a problem was become memories on } \\
\text { their life, make a short sentence }\end{array}$ \\
\hline
\end{tabular}

In the first cycle, the researcher gave teaching about the explanation of the differences in verb I, verb II, verb III. The researcher will later give a task regarding Recount text that uses past tense / verb III, therefore students must be able to understand the difference between verb Iverb III which is the researcher's duty to provide a full understanding of students. In this cycle students find it quite difficult to understand the difference between verb I, verb II, verb III, but there are some students who have studied this material before in other places, so that some of these students easily understand. To accelerate students' understanding of the material, researchers have several special tricks, namely providing question and answer questions and evaluating and reviewing together, so that students can easily understand why they know where the error lies in the answer. From these mistakes they made improvements by finding the answers themselves which were bombed by researchers.

In the second cycle students are given the task of making a story that discusses childhood. After students were given an explanation of verb I, verb II, verb III, the researcher gave the task of making a story about childhood in the form of an experience, in this cycles students began to ask a lot about the proper sentence structure.

In the third cycles students are assigned to make dialogue sentences with their group friends. students begin to develop knowledge of making an English sentence with the right sentence structure.
In the fourth cycle students are given the task of telling an impressed experience in their life. In this meeting the students were proficient in making English sentences based on grammar structures. Not only proficient in making sentences but also proficient in interpreting English vocabulary which is the main asset in understanding foreign languages.

In the first cycle the results of the student assessment obtained were 20.5 out of 40 students, in the second cycle the results of the student assessment were 72 scores from 40 students, while in the third cycle the results of student assessments increased to 85 from 40 students. In conclusion, in terms of the assessment of students obtained from each cycle, the quality of students' grades has increased.

The researcher can be sure that the POWER method is very effective in making it easier for students to learn. This means that using the POWER method is sufficient to provide positive stimulation or a separate stimulus for students to be more motivated and fond of learning to write.

POWER is the first method known to students at MTs Mahwil Ummiyah but students have succeeded in improving their learning to write since the POWER method was implemented, not only learning to write but also It is easier for students to master new vocabulary in a text.

\section{CONCLUSION}

Based on the results of research conducted at MTs Mahwil Ummiyah for four times face-to-face, in the first cycle the results of student assessments obtained were very low, but in the second to fourth cycles the student learning outcomes increased up to 85 out of 40 students.

Starting from the activities of students and teachers in learning. Students begin to be active and confident in expressing the results of their ideas in writing which are then read in front of the class. They are not afraid to be wrong because an error is a delayed truth, they said.

The teacher was able to liven up the classroom atmosphere by applying the POWER method to students, at the time of the implementation of the teacher's 
activities in the first cycle it did not succeed in influencing students to get good grades, so the researcher held a second cycle, third to fourth, until finally in the second to fourth cycle results the acquisition of student scores managed to get the value set in accordance with the KKM score of 75.

In the second cycle stage, almost all students have experienced an increase, including in class activities and students are able to be active and creative in learning, so as to obtain significant learning outcomes. The class average in cycle 1 reached $20.5 \%$,

\section{REFERENCES}

Mulyadi, M. 2011. Penelitian kuantitatif dan kualitatif serta pemikiran dasar menggabungkannya. Jurnal Studi Komunikasi Dan Media, 15(01), 138.

Nisa', B. 2017. Kesalahan Tata Bahasa while in the second cycle it reached $72 \%$ and in the third cycle it reached $85 \%$, meaning that the results of student assessments increased the students were increasingly supported in their learning motivation.

For the planning stage of the lesson plan, the school should develop it again so that students can learn more creatively so that students will be interested in the learning being carried out and the methods applied by the teaching teacher.

Grammar pada makalah mahasiswa Program Studi Bahasa Inggris. Jurnal Wanastra, 09(01), 23.

Nurkholis. 2013. Pendidikan dalam uaya

Memajukan Teknologi. Jurnal

Kependidikan, $\quad 01(01), \quad 44$. 